\title{
International smoke-free flights: buckle up for take-off
}

\section{What is the problem?}

Why should anyone make an issue of some passengers indulging in a few puffs on an aeroplane? An inconvenience maybe, but will breathing some cigarette smoke really harm anyone? The answer is yes - the important point being that nowhere is environmental tobacco smoke (ETS) exposure a greater risk than during a flight where many bodies are squeezed for long hours into a tiny space in which the tobacco smoke is recirculated.

A billion air travellers every year are at risk, especially frequent flyers, children and, with increased availability of flights, increasing numbers of the elderly or disabled.

An aircraft is also a workplace for hundreds of thousands of people. Flights expose flight crew and attendants to ETS for many hours at a time. The low humidity of the pressurised environment in today's aircraft magnifies tobacco smoke irritation of the lung, throat, nose, and eyes of those operating the controls. The majority of pilots in many countries are non-smokers. Many are former smokers fuming over ETS in the flight deck.

\section{What are the facts?}

Readers of this journal already know ETS is a common preventable cause of disease in non-smokers - cancer, heart disease, respiratory illnesses in children, asthma - to name a few. For health workers this is a dead issue, the evidence is overwhelming.

Frequent flyers would be few indeed if they were told, for example, that due to some technical difficulties aircraft cabins contained clouds of benzene gas, that asbestos particles were floating freely, or that they would be subjected to radon emissions. Unfortunately, because tobacco smoking was a feature of most flights before the dangers of ETS were discovered, public opposition to tobacco smoke in aircraft has been in slow motion. Fortunately, in the last couple of years, attitudes and policies are changing.

As the article "Passive smoking aboard passenger aircraft" by Burckhard Junge in this issue of Tobacco Control (see pp 50-8) makes abundantly clear, it is not possible to provide both a smoking environment and a totally smoke-free one on an aircraft. That's like trying to provide a chlorine-free end in the neighbourhood swimming pool. ETS simply cannot be contained in one area; recirculated fumes impinge on all occupants. There are only two solutions: 1) provide separately ventilated smoking areas, or 2) ban smoking. There are no available half measures. The former is virtually impossible; the latter the only realistic answer.

Although relatively few aircraft accidents have been assessed as definitely having been caused by smoking, the potential clearly exists and will increase as huge aircraft carrying 500 to 800 passengers come into operation. Indeed, even in a 400-passenger aircraft with 100 seats for smokers, the knowledge that some 100 naked flames will appear as soon as the "no smoking" sign goes off is never a reassuring thought.

The dangers of on-board furtive smoking have been recognised by civil authorities around the world and the technology exists to ensure that the cabin crew could be immediately alerted by any attempt to smoke or disable the warning system. Even more important from an aviation safety point of view, is the fact that the technology exists to install automatic fire extinguishers where there are combustible materials. This would be a good precaution whether or not the aircraft is to be operated as smoke-free transportation.

ETS exposes flight crew and cabin personnel to high concentrations of carbon monoxide over extended periods of time. This exacerbates decreased blood oxygen levels as altitude increases, which in turn impairs night vision and general performance.

Many nations are increasingly taking action to control ETS in public places and workplaces and aboard public transportation. Momentum is for health. Smoking bans on aircraft have been implemented by increasing numbers of airlines and legislated by a growing number of countries, and after a short adjustment period, the carriers, the cockpit and cabin crews, and the passengers have clearly welcomed the ban.

\section{What is the background?}

"Rendez-vous ' 91 ", a series of meetings organised by the Canadian Cancer Society in Ottawa and Montreal in February 1991, was the first international summit for smoke-free skies. It was attended by a number of tobacco control advocates from North American and European health agencies as well as flight attendant unions. The meetings were the first international gathering to plan a detailed strategy to obtain international smoke-free flights. One session was held with Transport Canada officials to discuss new Canadian legislation phasing in smoke-free international flights over a three-year period. Also included was a meeting with senior officials of the International Civil Aviation Organisation (ICAO), a United Nations body charged with developing international aviation in a safe and orderly manner. It was agreed by , those present that a network would be organised to enable sister health organisations around the globe to lobby ICAO member states on the issue.

In May 1991, the World Health Assembly passed a resolution urging all Member States "to ban smoking in public conveyances where protection against involuntary exposure to tobacco smoke cannot be ensured, and the adoption of effective smoke protection whenever possible". This passed unanimously, indicating that the resolution had broad support worldwide.

Over a thousand delegates at the April 1992 Eighth World Conference on Tobacco or Health held in Buenos Aires passed the following resolution: "The Conference strongly urges the International Civil Aviation Organisation to adopt provisions prohibiting smoking on all commercial, passenger aircraft flights, domestic and international, and to collaborate with the World Health Organisation."

A coalition of health workers around the world at a conference luncheon meeting in Buenos Aires organised by the Canadian Cancer Society and the American Lung Association has since been working behind the scenes in many countries and with international bodies to help them understand the health issues at stake.

Health groups were flying high after the triennial 
Assembly of ICAO took the strongest tobacco control steps to date by an international body. Representatives from 152 nations meeting in Montreal from 22 September to 8 October 1992 adopted a resolution, initiated by Australia and Canada, to prohibit smoking on all airline passenger flights worldwide. The resolution urged all Contracting States to take necessary measures as soon as possible to restrict smoking progressively on all international passenger flights with the objective of implementing complete smoking bans by 1 July 1996. There was active support at the meetings from officials of the World Health Organisation (WHO) - a welcome example of cooperation between international bodies. The key victory was getting a date for implementation specified as some countries were lobbying to leave it open-ended.

Assembly agreement was reached by unanimous consensus despite lobbying and fierce discussions behind the scenes. After the decision, however, the Delegate of the United Kingdom put on record that he felt the resolution was premature as it prejudged the outcome of technical studies on safety aspects of complete smoking bans. Furthermore, he stated that smoking on an aircraft should be a matter of judgment of the airlines that would have to implement the ban. Delegates from a number of countries associated themselves with that view: Spain, Germany, Denmark, Madagascar, Portugal, The Netherlands, Greece, Ireland, Mexico, Belgium and Sweden.

An important argument in convincing the Assembly to move on this issue was a reminder that, although flight safety is the primary objective of ICAO, it had also acted on other kinds of issues including aircraft engine emissions, depletion of the ozone layer, aircraft noise levels, and even social issues such as Apartheid. It was also pointed out to delegates that the WHO and the International Labour Organisation (ILO) stress that matters of occupational safety and health are interrelated, cannot be separated, and are reflected in many national occupational health and safety laws.

\section{Where do we go from here?}

Health organisations must not go to sleep thinking that the ICAO Assembly has spoken and all is well. The option of smoke-free flights is certainly seen by airlines to have marketing significance. They are feeling the impact of the current economic situation, and are motivated to avoid measures that could lose them passengers. Health organisations must therefore move with aviation speed to:

- Show government officials and airlines themselves that a number of airlines such as Air Canada and Cathay Pacific have aggressively marketed with "bottom-line" success a smoke-free environment.

- Work for measures which preclude the choice of smoking or smoke-free environment being a marketing factor for airlines.

- Underscore the importance of international cooperation in implementing the worldwide ban under the leadership of ICAO.
- Encourage governments to work for bilateral and multilateral agreements to phase in the ICAO ban while keeping level the airlines' competition playing field. For example, any two countries could agree to implement a smoking ban on all flights between them, with the ban applying not only to their respective airlines, but also to those of other countries allowed to provide air service between the signatory nations.

- Increase the number of smoke-free air routes to encompass large areas of the globe. A good start is currently being negotiated over the Pacific through an agreement between the US, Canada, Australia, and New Zealand.

- Urge governments and airlines to launch a campaign for a smoke-free transatlantic sky.

- Urge travel agents, their companies and trade associations in each country to publicise the availability of smoke-free flights. Non-smokers are often not informed by travel agents about smoke-free options.

- Lobby national governments to comply with a request of ICAO Secretary General, Dr Philippe Rochat, in a letter dated 14 September 1993 to Member States, requesting that smoking be banned by 14 December 1994 to mark the 50th anniversary of the signing of the Convention on International Civil Aviation at Chicago. That day has been declared International Civil Aviation Day.

- Urge national aviation authorities to respond to an ICAO questionnaire circulated in December 1993 on technical aspects of implementing the ban, about partial or total bans already in effect in each country, and about the intentions of civil aviation authorities in this regard.

- Put this issue on appropriate agendas for national health agency and coalition meetings as well as those of international bodies such as the International Union Against Cancer.

In conclusion, we must remember that much more is at issue here than frequent flying. As many international travellers are opinion leaders in their own countries, smoke-free flights can be a high-profile symbol of successful advocacy efforts in tobacco control. Countries moving ahead on this issue can become excellent role models for opinion leaders from other countries who can take home the message that it is important to eliminate ETS from places where people work, live, and travel.

Canadian Cancer Society, KEN KYLE

44 By Ward Market, Suite 230

Ottawa, Ontario, K1N $7 A 2$

Canada

American Lung Association, $1726 \mathrm{M}$ Street, $N W$, Suite 902,

Washington, DC 20032, USA 